\title{
MECHANICAL PROPERTIES OF BOTTOM ASH - DREDGED MATERIAL MIXTURES IN LABORATORY TESTS
}

\author{
LECH BAŁACHOWSKI, ZBIGNIEW SIKORA \\ Gdańsk University of Technology, Department of Geotechnics, \\ Geology and Maritime Engineering, ul. G. Narutowicza 11/12, 80-233 Gdańsk, Poland. \\ E-mail: abal@pg.gda.pl
}

\begin{abstract}
Bottom ash from EC Gdańsk and dredged material taken from the mouth of The Vistula were mixed to form an engineering material used for dike construction. Mixtures with different bottom ash content were tested in laboratory to determine its basic physical and mechanical properties. The optimum bottom ash-dredged material mixture, built in the corps of the test dike, contains $70 \%$ of ash. The optimum bottom ash content in the mixture was chosen taking into account high internal friction angle, good compaction and reduced filtration coefficient. The maximum dry density of the mixtures was measured in Proctor test for the mixtures formed in laboratory and on samples taken from the test dike. Minimum and maximum void ratio were also determined.
\end{abstract}

\section{INTRODUCTION}

The use of anthropogenic material in large infrastructural projects and the determination of mechanical properties of such a material constitutes an important challenge for geotechnical engineering, Batog and Hawrysz [1], Zabielska-Adamska [2], Sas et al. [3], Kokusho [4]. Innovative method of dike construction uses the mixtures of widely available bottom ash from electro power station and dredged material taken from the mouth of the Vistula, where a steady effort is applied to keep the outlet of the river clean to allow unrestricted flow of floes and the flood prevention. The huge amount of dredged material, extracted during this process, can be used as a granulate in road embankments and also to construct, rebuilt or renovate the existing dikes, Sikora [5]. One should consider the economical and environmental impact of such a solution, especially in the deltaic area, where mineral materials are hardly available, its transport is inefficient, expensive and has a big environmental impact in terms of pollution, noise and congestion. On the other hand, river dredged material, systematically extracted, can be readily available with a minimal transport efforts, especially in dike application. The bottom ash from coal burning municipal electro power stations, deposited in waste disposals, together with dredged material can be used as an engineering material. Common DredgDikes project with the lead partner from Rostock University is being realized within the frame of the South Baltic Programme. An important part of the project is the construction of the test dikes in Germany and Poland and a comprehensive experimental program considering hydraulic and environmental studies. 


\section{TEST DIKE}

The test dike $3 \mathrm{~m}$ high was built on the bank of the Vistula in Trzcińsko. The clay layer was put on the ground level in order to make an impervious layer at the bottom and to avoid filtration under the dike. The clay cover was also installed on the dike slope to reduce the filtration through the corps and to protect the mixture material. Aerial slope was reinforced with special bottom ash-soil mixture Tefra. The test dike was covered with grass. A view of the test dike is given in Fig. 1. The hydraulic tests will be performed within the area limited with the sheet pile wall. The dike is instrumented with gauges of water content and piezometers, Ossowski and Wyroślak [6].

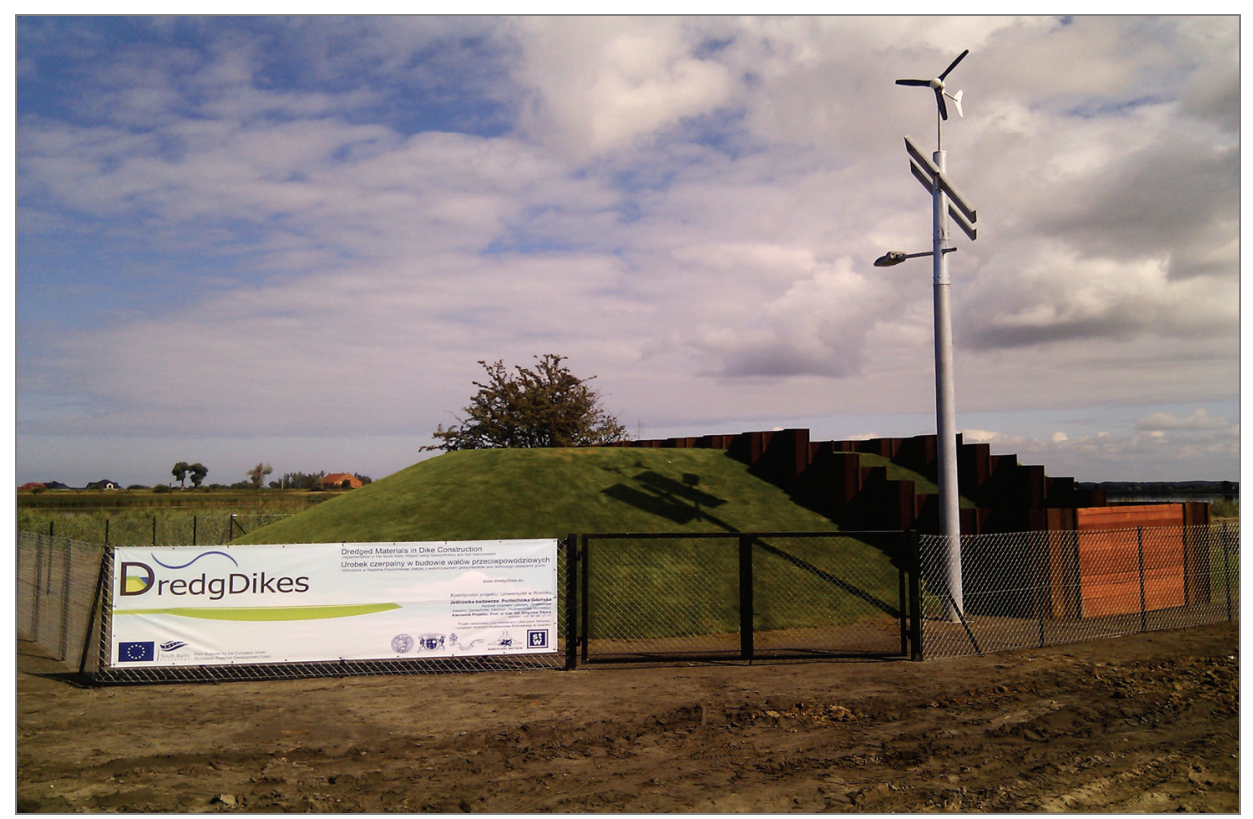

Fig. 1. View of the test dike

\section{PROGRAM OF LABORATORY TESTS}

The aim of the laboratory tests was to determine basic soil properties, soil strength and compressibility, compaction and permeability parameters. The tests were made on dredged material and bottom ash itself and the mixtures with different bottom ash content. The mixtures were prepared using volumetric ratios. The goal of the laboratory studies is also to choose the optimum bottom ash-dredged material mixture to be applied at the test site. Additional laboratory experiments were made on the disturbed and undisturbed samples taken from the dike corps. 


\section{BASIC SOIL PROPERTIES}

Basic soil properties include granulometry, specific gravity, $\mathrm{pH}$ factor. Granulometry curves for dredged material and bottom ash are given in Fig. 2 and Fig. 3. One should notice a very uniform granulometric curve and small amount of fines in both cases. The granulometry and specific density is described with the parameters given in Table 1 .

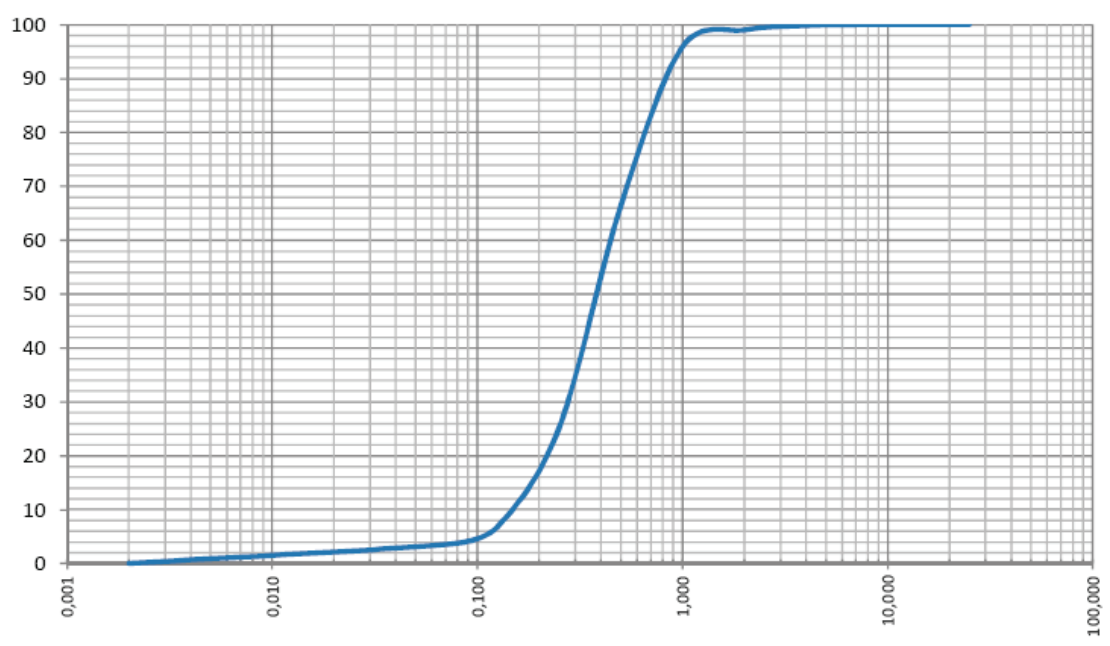

Fig. 2. Granulometry of dredged material

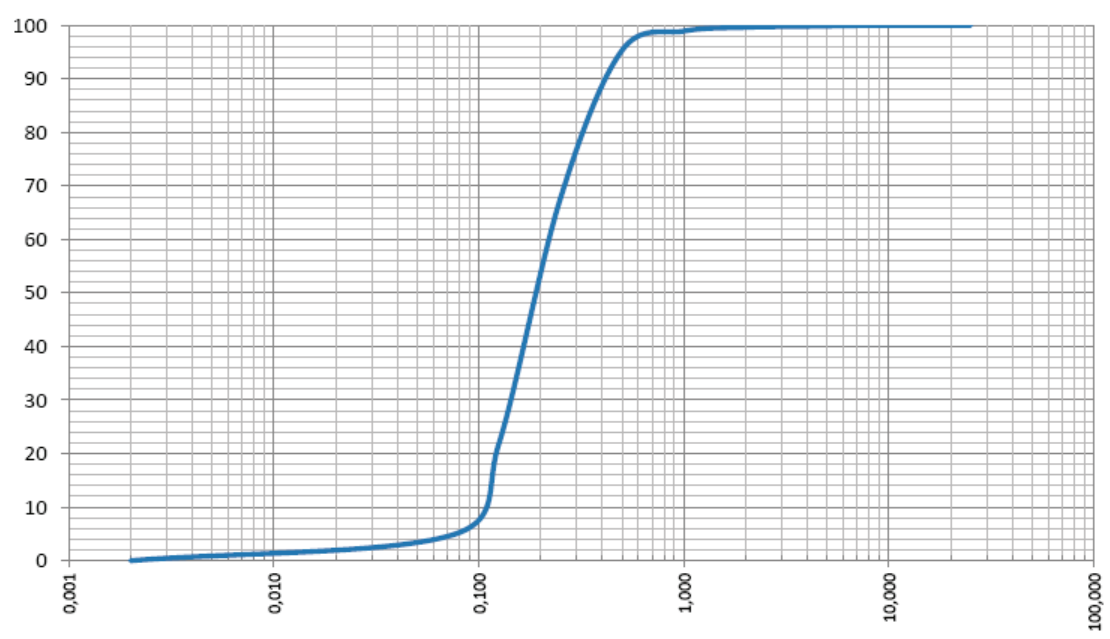

Fig. 3. Granulometry of bottom ash

Mean specific gravity of dredged material was determined as $2.67 \mathrm{~g} / \mathrm{cm}^{3}$. Mean specific gravity of bottom ash was estimated as $1.87 \mathrm{~g} / \mathrm{cm}^{3}$, being in the range from 
$1.77 \mathrm{~g} / \mathrm{cm}^{3}$ to $1.95 \mathrm{~g} / \mathrm{cm}^{3}$. The determined average $\mathrm{pH}$ of the bottom ash: $\mathrm{pH}=9.51 \pm$ 0.17 , which means that the material is moderately alkaline.

Table 1

Granulometry and specific gravity of the bottom ash and dredged material

\begin{tabular}{|l|c|c|}
\hline \multicolumn{1}{|c|}{ Parameter } & Bottom ash & Dredged material \\
\hline Uniformity coefficient $U$ & 2.00 & 3.14 \\
\hline Curvature coefficient $C_{c}$ & 0.87 & 1.3 \\
\hline Mean grain diameter $d_{50}[\mathrm{~mm}]$ & 0.2 & 0.4 \\
\hline Specific gravity $\rho_{s}\left[\mathrm{~g} / \mathrm{cm}^{3}\right]$ & 1.87 & 2.67 \\
\hline
\end{tabular}

\section{COMPACTION PROPERTIES}

The tests were made in $1 \mathrm{dm}^{3}$ mould with three layers of materials compacted with 25 blows of the rammer. The optimum water content and the maximum dry density were determined for a given bottom ash-sand mixture. The compaction curves are rather flat and the maximum dry density is not well defined, as the materials are difficult to compact, Sas et al. [3] (Fig. 4). There is also a modification of the bottom ash granulometry due to grain crushing during compaction, as was shown by ZabielskaAdamska [2]. Generally, dry density decreases (Fig. 5) and optimum water content increases with bottom ash content (Fig. 6). Proctor test was made also for the samples taken from the dike corp. A good agreement was found for the compaction test results on laboratory prepared mixture (70/30) and the mixture taken from the test dike.

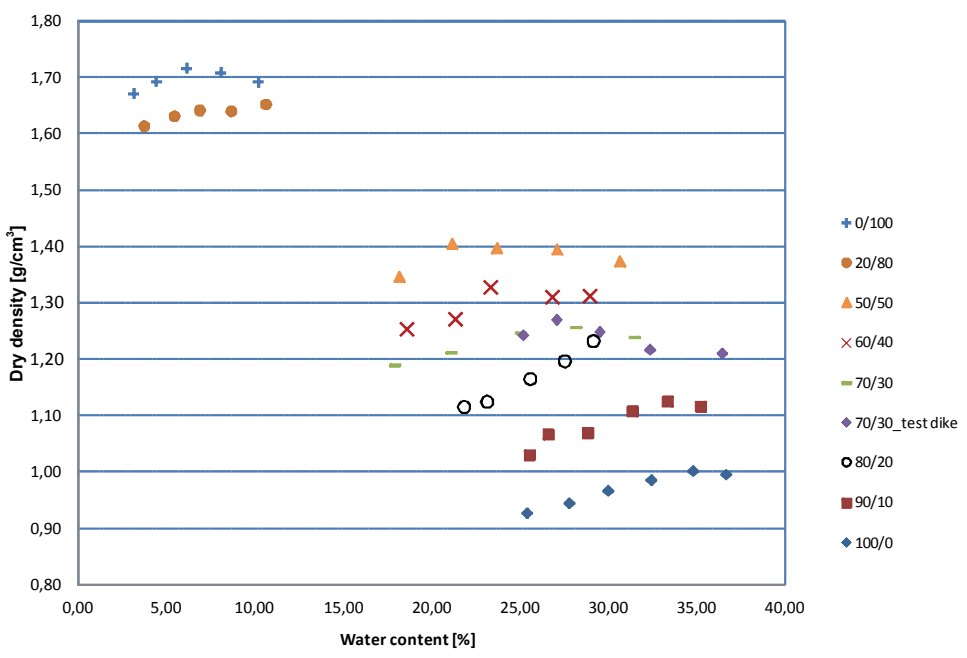

Fig. 4. Dry density vs. water content for three bottom ash-sand mixtures 


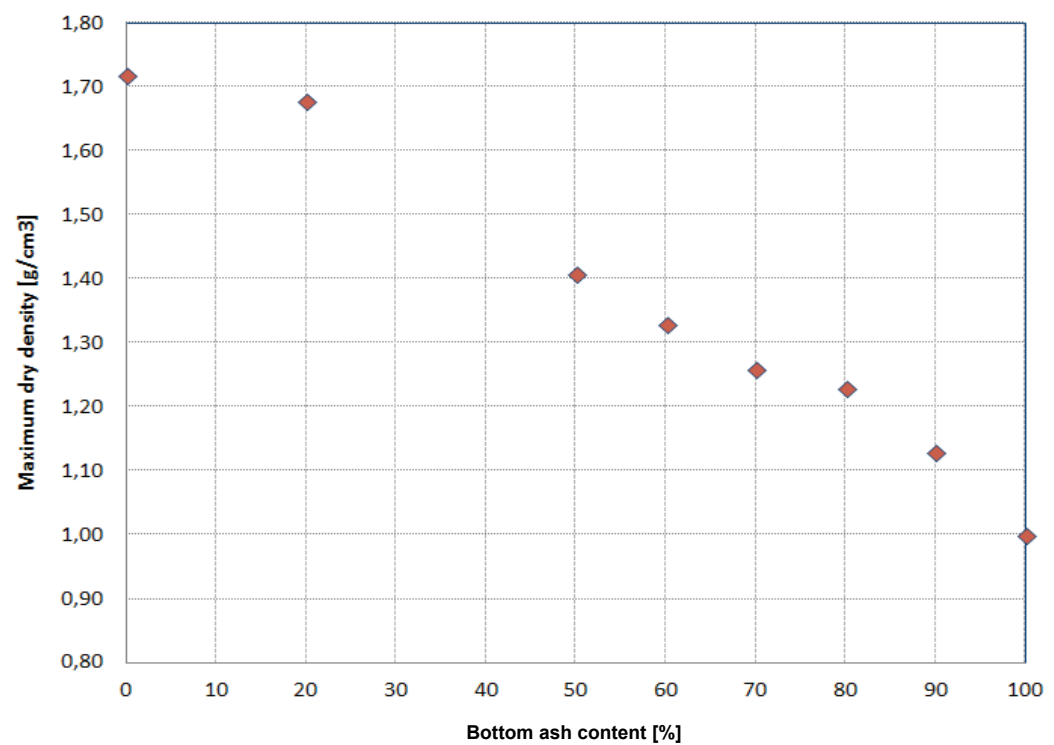

Fig. 5. Maximum dry density vs. bottom ash content

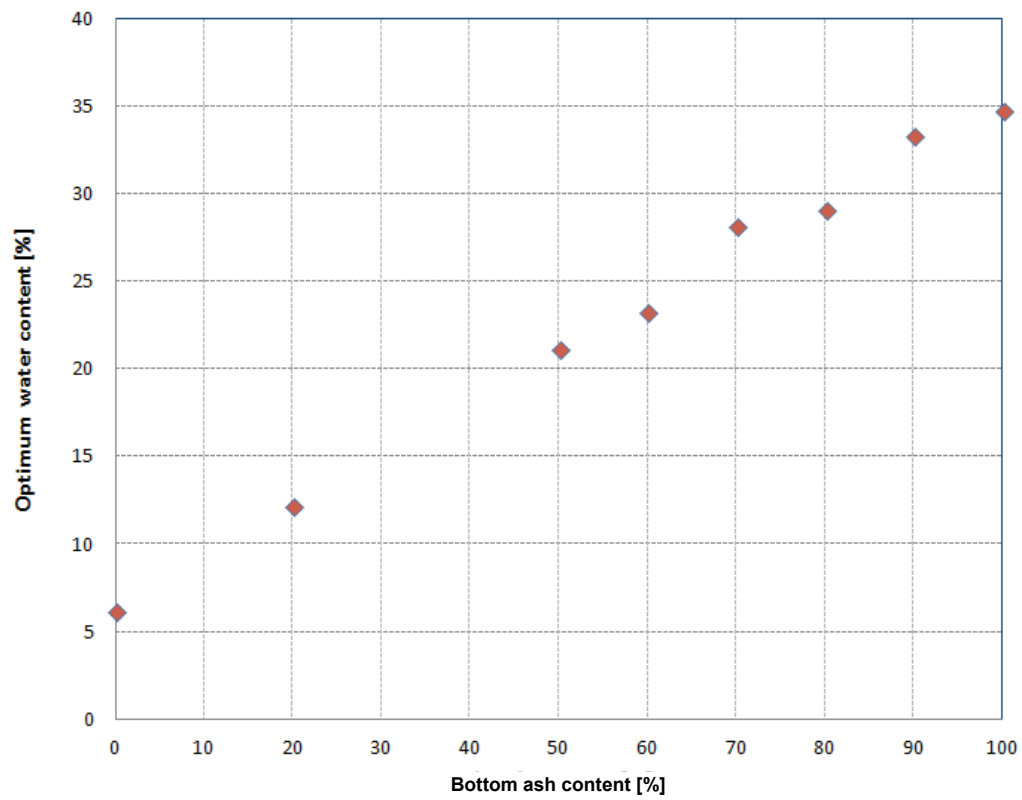

Fig. 6. Optimum water content vs. bottom ash content

Minimum and maximum void ratio for the same mixtures as used in Proctor tests were determined. Both minimum and maximum void ratio increase with bottom ash 
content (Fig. 7). The difference $e_{\max }-e_{\min }$ is getting bigger for higher bottom ash content. The optimum value of void ratio at maximum dry density from Proctor test was also plotted on the same graph. Void ratio at the maximum dry density is close to minimum void ratio.

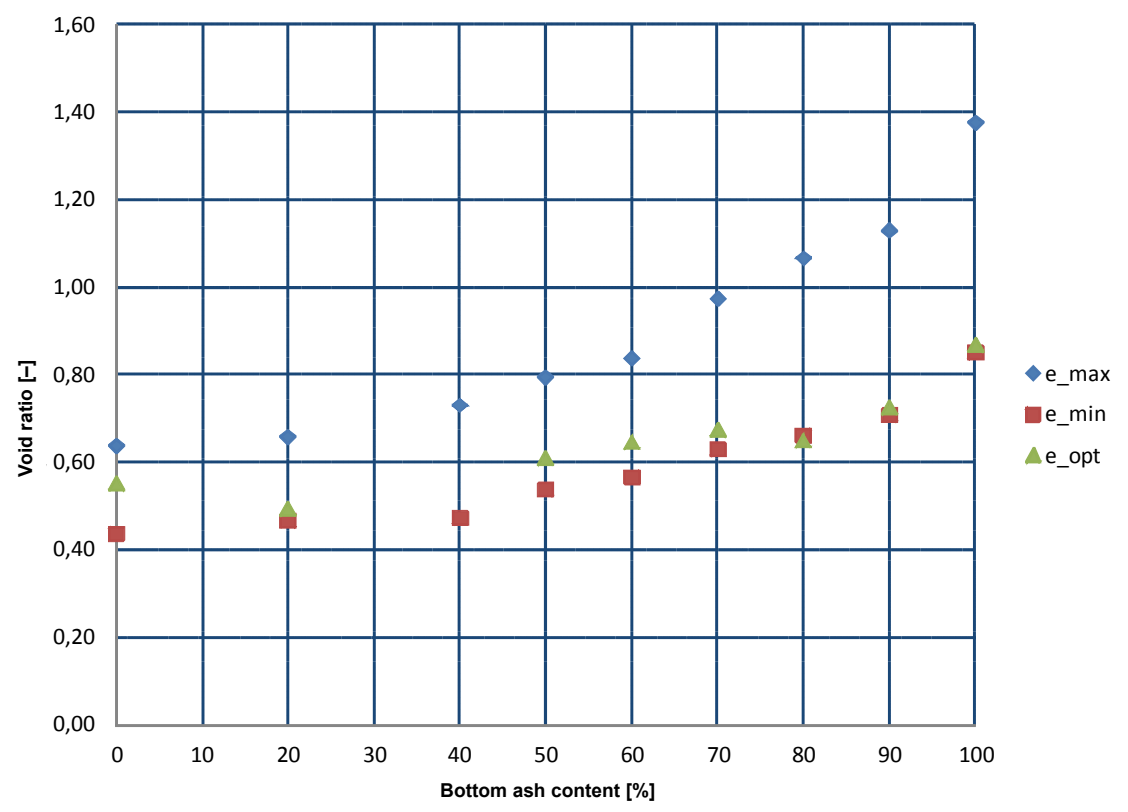

Fig. 7. Minimum and maximum void ratio vs. bottom ash content

\section{SHEAR STRENGTH OF THE MIXTURES}

Some complementary direct shear tests for the mixtures with various bottom ash content were made to estimate variation of internal friction angle and cohesion. The tests were made on reconstituted samples at water content slightly lower than the optimum water content. Generally, angle of internal friction decreases with bottom ash content. However, a local minimum is observed for the mixtures with about $90 \%$ of bottom ash content (Fig. 8). For the mixture used in the test dike (70/30) the angle of internal friction is close to 38 degrees. The measured cohesion is negligeable for low bottom ash content and slightly increases to several $\mathrm{kPa}$ for higher bottom ash content (Fig. 9). For the mixture used in the test dike (70/30) the cohesion is close to $5 \mathrm{kPa}$. Some drained and undrained triaxial tests are also performed on undisturbed samples taken from the dike corps. The angle of internal friction is close to that obtained for $(70 / 30)$ mixture in direct shear tests. 


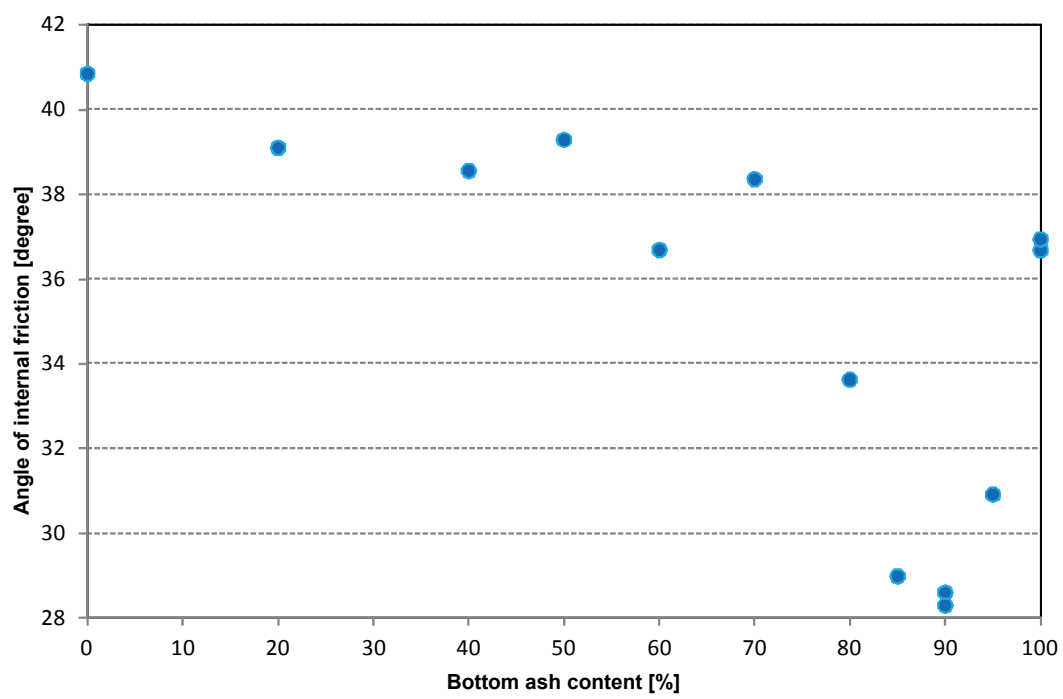

Fig. 8. Angle of internal friction for various mixtures

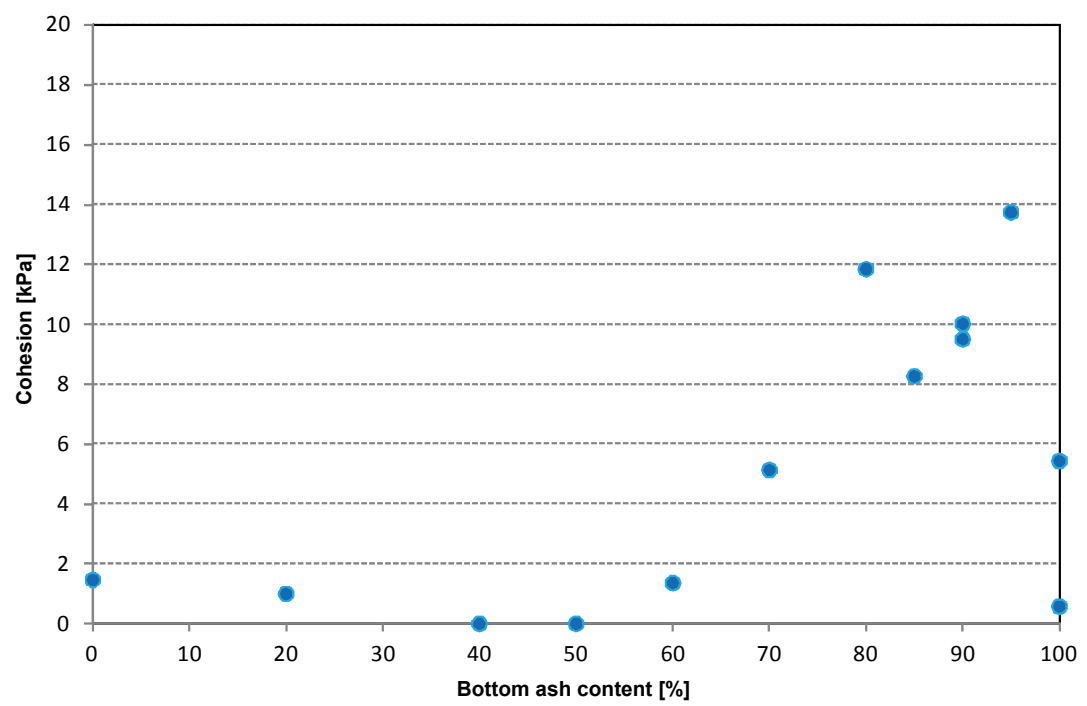

Fig. 9. Cohesion for various mixtures

\section{HYDRAULIC CONDUCTIVITY}

Initially, the hydraulic conductivity of the optimum bottom ash-dredged material mixture (70/30) was measured in constant head apparatus on a fresh sample reconsti- 
tuted in laboratory. In this case the hydraulic conductivity of fresh mixture $k_{10}$ was estimated to be close to $9.4 \cdot 10^{-5} \mathrm{~m} / \mathrm{s}$. Hydraulic conductivity was also measured on (70/30) mixture sample taken from the dike core. The test was performed during 3 weeks (Fig. 10). The plotted values of hydraulic conductivity corrected for temperature effect are decreasing with time, considered from the dike construction. Finally, this coefficient after 2 weeks of measurements has stabilized. The hydraulic conductivity corrected for temperature effect $k_{10}$, was estimated to be close to $1.3 \cdot 10^{-5}$ $\mathrm{m} / \mathrm{s}$. It is about 7 times lower than that one measured on the laboratory prepared (70/30) mixture.

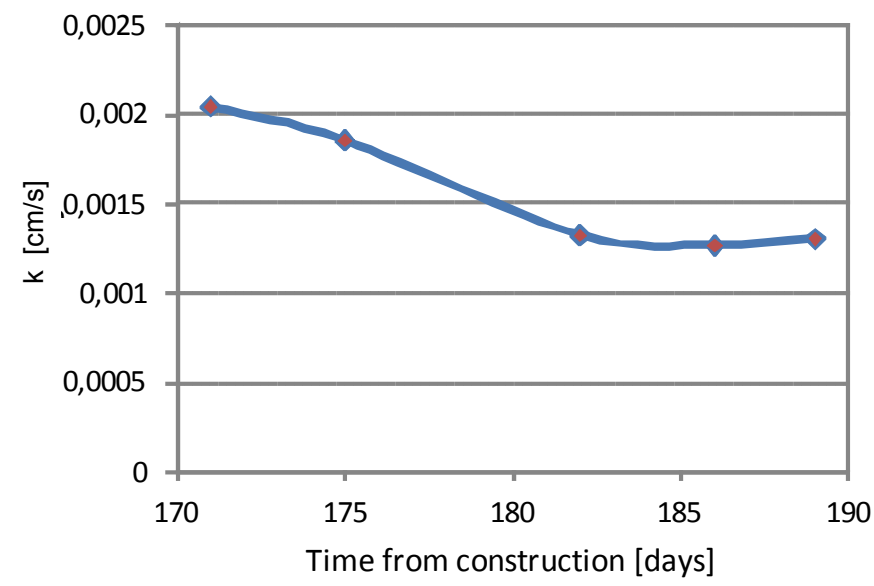

Fig. 10. Hydraulic conductivity of the sample taken from the dike corps

\section{CONCLUSION}

A series of laboratory tests were performed to determine basic physical and mechanical parameters of dredged materials, bottom ash and their mixtures. Angle of internal friction decreases with bottom ash content, with local minimum near $90 \%$ bottom ash content. Small cohesion intercept was found at higher bottom ash content. Bottom ash is very heterogeneous material with specific density varying from 1.77 to $1.95 \mathrm{~g} / \mathrm{cm}^{3}$.

The optimum water content range and maximum dry density was determined in Proctor tests. The maximum dry density decreases with bottom ash content, while the optimum water content increases. Void ratio at maximum dry density is close to the minimum void ratio.

Taking into account the results of direct shear and Proctor tests the optimum mixture bottom ash-sand (70/30) was chosen for test dike construction.

Hydraulic conductivity, estimated in laboratory, decreases with time measured from the construction period. 


\section{ACKNOWLEDGEMENTS}

The experiments were realized within DredgDikes project 2011-2013 part-financed by UE funds (ERDF) in the frame of the South Baltic Programme. The authors appreciate students' voluntary work during this project.

\section{REFERENCES}

[1] Batog A., Hawrysz M., Przydatność mieszanek popiołowo-gruntowych do budowy nasypów komunikacyjnych, Górnictwo i Inżynieria, 2010, Zeszyt 2, 69-75.

[2] ZABIELSKA-ADAMSKA K., Laboratory compaction of fly ash and fly ash with cement additions, Journal of Hazardous Materials, (151) 2008, 481-489.

[3] SAS W., SzYMAŃSKi A., MalinOwSKA E., GABRYŚ K., Geotechniczne uwarunkowania zastosowania materiatów antropogenicznych w budownictwie, Inżynieria Morska i Geotechnika, 2012, nr 4, 376-380.

[4] Konusho T. et al., Soil investigation of fly ash deposits improved by heavy compaction method, Journal of Geotechnical and Geoenvironmental Engineering, ASCE, 2012, 6, 738-746.

[5] SiKORA Z., Renowacja wałów przeciwpowodziowych, Inżynier Budownictwa, 2011, nr 4, 69-72.

[6] OSSOwSKi R., WyRoŚLAK M., Hybrydowa technologia wzmacniania gruntu $w$ renowacji wałów przeciwpowodziowych, Inżynieria Morska i Geotechnika, 2012, nr 4, 483-486. 